\title{
STRATEGI GURU DALAM MENGATASI KESULITAN BELAJAR PESERTA DIDIK PADA MATA PELAJARAN AL-QUR'AN HADIST
}

\author{
Muh. Irawan Zuliatul Apri, H. Hakkul Yakin \\ Dosen Tetap Program Studi Pendidikan Agama Islam \\ IAI Hamzanwadi NW Lombok Timur \\ Email: ir.apri743@gmail.com
}

\begin{abstract}
Abstrak: Penelitian ini dilatar belakangi oleh sebuah fenomena bahwa dalam proses belajar mengajar di sekolah dijumpai siswa pada sekolah tersebut mengalami kesulitan belajar, terlebih pada mata pelajaran Al-Qur'an Hadits. Kesulitan belajar tersebut dapat timbul dari berbagai faktor. Jika kesulitan-kesulitan yang ada itu tidak diatasi dengan seksama maka akan mempengaruhi pada keberhasilan belajar siswa. Oleh karena itu, berbagai pihak yang bersangkutan berusaha mengatasinya guna tercapainya tujuan pendidikan yang seoptimal mungkin. Penelitian ini disusun berdasarkan data lapangan yang menggunakan pendekatan kualitatif. Data dikumpulkan dengan menggunakaan metode observasi, wawancara mendalam dan dokumentasi. Setelah penulis mengadakan penelitian dengan beberapa metode diatas memperoleh hasil bahwa: (1) Jenis kesulitan belajar yang dihadapi oleh siswa pada mata pelajaran Al-Qur'an Hadits di MTs Nurul ljtihad NW Tenang adalah kesulitancmembaca Al-Qur'an dan kesulitan dalam menghafal Al-Qur'an dan Hadits (2) Strategi yang dilakukan oleh guru dalam mengatasi kesulitan belajar siswa padamata pelajaran Al-Qur'an Hadits di MTs Nurul ljtihad NW Tenang yaitu dengan cara: pemberian motivasi, penggunaan fasilitas seperti media LCD proyektor, penggunaan aplikasi google classroom, pengadaan madrasah diniyah.
\end{abstract}

Kata Kunci: Kesulitan Belajar Peserta didik, Strategi Guru

Abstract: This research is driven by the phenomenon that in the process of teaching and learning in schools students are found to face learning problems, especially in the subject of Qur'an Hadith. Learning difficulties can arise from a variety of factors. If the existing difficulties are not addressed carefully, it will affect the learning success of the students. Therefore, various parties concerned are working to overcome it to achieve optimal educational goals. This research was compiled based on field data using a qualitative approach. Data were collected using observation methods, in-depth interviews, and documentation. After the author conducted research using some of the above methods, the results showed that: (1) The type of learning difficulties faced by students in the subject of AlQur'an Hadith in MTs Nurul ljtihad NW Calm is difficulty in reading Al-Quran and difficulty in memorizing Al -Quran. Al-Qur'an and Hadith (2) Strategies undertaken by teachers in overcoming student learning problems in the subject of Al-Qur'an Hadith in MTs Nurul ljtihad NW Tenang, namely by: motivating, using facilities such as LCD projector media, using google class application, madrasah acquisition diniyah.

Keywords: Student Learning Difficulties, Teacher Strategies 


\section{PENDAHULUAN}

Keberhasilan suatu Negara tidak terukur dari melimpah ruahnya sumber daya alam. Akan tetapi, faktor terpenting yang menentukan keberhasilan suatu Negara ialah terukur dari kualitas sumber daya manusianya (SDA). Bahkan ada yang mengatakan "bangsa yang dapat dilihat dari kualitas/karakter bangsa (manusia) itu sendiri”. Abdul Majid (2011:2). Hal tersebut menunjukkan betapa pentingnya pendidikan dan kualitas pendidikan demi terciptanya sumber daya manusia yang berkualitas.

Pendidikan adalah usaha sadar dan terencana secara etis, sistematis, intensional, dan kreatif dimana peserta didik mengembangkan potensi diri, kecerdasan, pengendalian diri dan keterampilan untuk membuat dirinya berguna. Muzakki Rahmatullah (2018:25). M Tholhah Hasan (2003:199) mengemukakan bahwa Pendidikan juga dapat diartikan sebagai cara dalam menciptakan sebuah potensi-potensi dasar yang dimiliki oleh peserta didik dan dapat dikembangkan sesuai dengan kebutuhan mereka, agar dapat menghadapi tuntutan zaman. Namun realita pendidikan saat ini jauh dari harapan. maka untuk itu perlu ada perbaikan dan perbenahan yang harus dilakukan, baik secara bertahap atau terus-menerus demi tercapainya tujuan menghasilkan Sumber Daya Manusia (SDA) yang berkualitas.

Dengan adanya berbagai tuntutan dalam dunia pendidikan, maka guru adalah sosok terpenting yang ikut serta dalam menciptakan sumber daya manusia yang unggul dan berkualitas. Guru merujuk pada seseorang yang harus digugu dan ditiru. Guru dalam arti digugu adalah sesuatu yang disampaikannya senantiasa dipercaya dan diyakini kebenarannya oleh peserta didik. Sedangkan di tiru adalah dalam arti seorang guru harus mampu memberikan suri tauladan (panutan) yang baik bagi seluruh peserta didik.

Hakikatnya, guru bertanggung jawab penuh atas terselenggaraya proses belajar mengajar dengan baik demi tercapainya tujuan pendidikan nasional. Ridho Putra Setiawan (2018:2) mengemukakan bahwa guru juga harus memberikan pendidikan kepada semua peserta didiknya secara merata tanpa harus membedakan staus social, ekonomi, agama, suku, bangsa, dan lain sebagainya. Hasbullah (1999:125) mengutarakan bahwa hal ini tertuang dalam UU Nomor 2 Tahun 1989 pasal 6, yaitu:

Setiap warga negara berhak atas kesempatan yang seluas-luasnya untuk mengikuti pendidikan agar memperoleh pengetahuan, kemampuan dan keterampilan yang sekurangkurangnya setara dengan pengetahuan, kemampuan dan keterampilan Pendidikan Dasar.

Seorang guru harus mampu memahami karakteristik, kepribadian setiap peserta didik yang mulai dari perekembangan fisik, intelektualitas, kebutuhan yang diperlukan sehingga guru dapat menentukan tindakan-tindakan ataupun metode dan strategi pembelajaran yang dapat menumbuhkan semangat belajar yang tinggi bagi peserta didik.

Dengan adanya semangat belajar yang tinggi pada siswa dapat menumbuhkan hal positif yang memberikan dorongan serta semangat belajar dari satu tahap ke tahap berikutnya sesuai dengan perkembangan yang dialami oleh individu peserta didik. Dalam kegiatan proses belajar mengajar sudah barang tentu ada sesuatu yang diharapkan yaitu memperoleh hasil yang maksimal. Namun realitanya dalam kegiatan belajar mengajar banyak sekali rintangan, hambatan dan kesulitan-kesulitan yang dialami oleh peserta didik.

Pada hakekatnya setiap anak didik pergi ke sekoah tidak lain kecualiuntuk belajar agar menjadi orang yang berilmu dan berpengetahuan dikemudian hari. Sebagian besar waktu digunakan untuk belajar oleh pesertadidik, tidak mesti disekolah, bahkan di rumah pun harus ada waktu yangdiluangkan untuk beajar. Tiada hari tanpa belajar adalah ungkapan yang tepat bagi anak didik. Demikian yang dikatakan oleh Syaiful Bahri Djamarah (2011:233).

Selanjutnya ada yang mendefinisikan "belajar adalah berubah ubah". Dalam hal ini yang dimaksudkan belajar berarti usaha mengubah tingkah laku. Jadi belajar akan 
membawa suatu perubahan pada individuindividu yang belajar. Perubahan tidak hanya ilmu pengetahuan, tetapi juga berbentukkecakapan, keterampilan, sikap, pengertian, harga diri, minat, watak danpenyesuaian diri. Demikian dikatakan oleh Mulyono Abdurrahman (2003:6).

Pengertian yang lebih jelas dari uraian diatas mengenai makna belajar, perlu kiranya kita simpulkan bahwa belajar adalahsuatu usaha sadar manusia untuk melakukan perubahan yang lebih baik padasetiap tingkahlaku, pengetahuan maupun pengalaman yang dipelajarinya. Perestasi belajar yang optimal dapat diraih oleh setiap anak didik jikamereka mendapatkan pembelajaran secara wajar. Akan tetapi, aktivitas belajarbagi setiap individu tidak selamanya dapat berlangsung secara wajar, kadangkadang lancar, kadang-kadang tidak, kadang-kadang dapat cepat menangkap apa yang dipelajari, kadang-kadang terasa amat sulit.

Dalam hal ini semangat terkadang semangatnya tinggi, tetapi terkadangjuga sulit untuk mengadakan konsentrasi. Demikian dikatakan oleh M Dalyono (2007:229). Tidak hanya dirasakan oleh oleh sekolah modern perkotaan saja, tapi juga dirasakan oleh sekolah tradisional yang ada dipedesaan. Demikianlah realita yang kita jumpai pada anak didik dalam proses belajar-mengajar sehari-hari. Suatu hal yang tidak dapat dipungkiri bahwasanya setiap pribadi tidaklah sama, dimana masing-masing individu mempunyai karakteristik yang bermacam-macam. Karakteristik inilah yang menyebabkan perbedaan dalam tingkah laku belajar siswa. Pada intinya suatu keadaan dimana anak didik/ siswa tidak dapat belajar sebagaimanmestinya disebut sebagai "kesulitan belajar". Kesulitan belajar yang dialami oleh siswa perlu mendapatkan perhatian khusus dari kalangan pendidik, sebab hal ini akan memberikan dampak negative bagi siswa maupun lingkunganya.

Ridho Putra Setiawan (2018:4) mengatakan bahwasanya "hal tersebut merupakan tantangan tersendiri bagi kalangan pendidik". Kegagalan siswa dalam memahami pelajaran akan menimbulkan setres sehingga dapat menimbulkan banyak hal negative, seperti rasa malas untuk bersekolah, terjerumus kepada pergaulan yang salah, mengganggu teman saat kegiatan belajar mengajar berlangsung, dan banyak hal negative lainnya.

Al-Qur'an Hadist merupakan salah satu mata pelajaran PAI yang menerapkan tema tentang manusia dan tanggung jawab serta fungsinya di muka bumi. Secara substansial mata pelajaran al-qur'an hadist memiliki kontribusi fundamental dalam rangka mempelajari dan mempraktikan ajaran-ajaran yang terkandung dalam Al-Qur'an dan Hadist sebagai sumber utama ajaran agama Islam.

Dewasa ini banyak generasi ditengah masyarakat yang sulit mempelajari al-qur'an dan hadist. Pemandangan lain yang cukup memperhatikan adalah menurunya kecintaan generasi saat ini terhadap Al-Qur'an dan Hadist. Untuk itu, demi mewujudkan pendidikan yang lebih unggul dibidang keagamaan, tentunya pemerintah menjadikan al-qur'an hadist sebagai mata pelajaran disekolah-sekolah islam di Indonesia. Dengan di kelola oleh kementrian agama yang membawahi sekolah-sekolah islam di Indonesuia negeri maupun swasta dengan kurikulum yang sama-sama mengembakan ajaran islam. Al-Qur'an Hadist selain di pelajari di madrasah Tsanawiyah, Al-Qur'an Hadist juga di pelajari di madrasah tingkat lanjutan yaitu Madrasah Aliyah.

\section{METODE PENELITIAN}

Penelitian ini merupakan penelitian kualitatif deskriftif yang bertujuan untuk mendeskrifsikan bagaimana strategi guru dalam mengatasi kesulitan belajar siswa. Penelitian ini dilakukan MTs Nurul ljtihad NW Tenang Desa Segala Anyarm Kec. Pujut Kab. Lombok Tengah. Teknik pengumpulan data meliputi studi dokumentasi, observasi, dan 
wawancara mendalam. Analisis data menggunakan Model Miles and Huberman: (1) Pengumpulan data, (2) Reduksi Data, (3) Display Data, (4) Verifikasil Kesimpulan.

\section{HASIL DAN PEMBAHASAN}

1. Kesulitan Membaca Al-Qur'an

Pendidikan merupakan suatu proses pembelajaran yang mencakup tiga aspek yaitu kognitif, afektif, dan psikomotorik. Aspek-aspek tersebut harus dilaksanakan secara seimbang agar tujuan suatu pendidikan dapat tercapai. Untuk mencapai tujuan tersebut, maka diperlukan komponen yang mendukung proses pendidikan. Salah satu komponen yang berpengaruh dalam suatu pendidikan adalah seorang guru, dimana seorang guru harus mampu menjalankan tugasnya secara professional, tugas seorang guru tidak hanya menyampaikan pelajaran saja akan tetapi juga mengaplikasikannya dalam pembelajaran serta menjadi suri tauladan yang baik. Namun pada kenyataanya kegiatan belajar setiap individu, tidak selalu berjalan dengan lancar dan efektif, misalnya dalam hal konsentrasi maupun pemahaman materi yang telah disampaikan oleh guru. Kejadian seperti itu sering terjadi dan kita jumpai dalam proses pembelajaran. Seperti halnya yang terjadi di MTs Nurul ljtihad NW Tenang, dalam hal belajar AI Qur'an Hadits peserta didik masih banyak yang mengalami kesulitan belajar. Pada dasarnya Al-Qur'an Hadits itu tidak hanya berisi tentang pengertian Al-Qur'an dan hadits melainkan cara membaca, menulis dan menghafal bacaan Al-Qur'an hadits secara baik dan benar. Jadi, akan menyulitkan bagi mereka yang masih awam dengan AI-Qur'an. Sebagaimana yang dipaparkan oleh Bapak Mustofa selaku guru Al-Qur'an Hadits:

Kesulitan belajar siswa itu pasti ada, sama halnya dengan pelajaran yang lainnya. Dalam konteks pelajaran Al-Qur'an Hadits kesulitan utama yang dialami oleh siswa yaitu dalam hal membaca Al-Qur'an. Terutama anak yang berasal dari SD belum banyak yang bisa membaca dan menulis Al-Qur'an, sedangkan anak yang berasal dari MI dan anak yang sudah bisa membaca Al-Qur'an itu tidak terlalu mengalami kesulitanbelajar. Demikian wawancara dengan Ustaz Banyu Pratama Udali.

Kesulitan belajar yang dialami oleh siswa akan berdampak pada proses pembelajaran, dan proses pembelajaran pun tidak bisa menunai hasil secara maksimal. Hal ini dapat diketahui berdasarkan gejala-gejala kesulitan belajar yang dialami oleh siswa ketika pembelajaran Al-Qur'an Hadits sedang berlangsung, seperti yang telah dijelaskan oleh Ustaz Banyu Pratama Udali:

"Ada sebagian siswa yang kurang tanggap saat pembelajaran Al-Qur'an Hadits sedang dilaksanakan, misalnya saja ketika diberikan suatu evaluasi sederhana seperti membaca dan menulis Al-Qur'an, ternyata masih banyak siswa yang belum bisa. Hal tersebut dapat diketahui berdasarkan hasil evaluasi yang telah dikerjakan oleh siswa.

\section{Kesulitan Menghafal Ayat Dan Hadits}

Metode menghafal saat ini sudah mulai berkurang, padahal metode ini sudah diterapkan secara efektif pada zaman Rosulallah. Akibatnya banyak anak zaman sekarang yang kesulitan dalam hal menghafal. Setelah selesai wawancara dengan bapak Banyu Pratama Udali, peneliti mewawancarai siswa yang yang telah ditunjuk oleh bapak Banyu Pratama Udali dimana siswa tersebut dianggap mengalami kesulitan belajar. Siswa tersebut bernama Fauzan Azima berasal dari kelas VIII. Berikut keterangan dari Fauzan Azima kelas VIII:

"Dalam pembelajaran Al-Qur'an Hadits saya mengalami beberapa kesulitan belajar, diantaranya belajar membaca, dan menghafal Al-Qu'ran, karena pada dasarnya saya 
berasal dari Sekolah Dasar dan tidak ikut TPQ. Tapi, dengan adanya Madrasah Diniyah yang diadakan oleh sekolah sebelum jam pelajaran formal dimulai sedikit demi sedikit saya dapat mengatasi kesulitan belajar yang saya alami.

Tingkat kemampuan setiap siswa yang berbeda-beda merupakan tugas yang berat bagi guru Al-Qur'an Hadits. Karena, dengan perbedaan kemampuan pastinya kesulitan yang ditimbulkan juga akan berbeda. Dilihat dari riwayat jenjang sekolahnya, kebanyakan siswa dari Madrasah Ibtidaiyah lebih mudah untuk menerima pelajaran Al-Qur'an Hadits karena mereka sudah dikenalkan terlebih dahulu mengenai pelajaran Al-Qur'an Hadits, sedangkan siswa yang berasal dari Sekolah Dasar akan merasa kesulitan dalam menerima pelajaran Al-Qur'an Hadits karena siswa kurang mendapatkan pelajaran yang berkaitan dengan hafalan ayat Al-Qur'an dan hadits. Menurut observasi peneliti adalah sebagai berikut:

Kesulitan yang dialami siswa pada mata pelajaran AI-Qur'an Hadits tidaklah sama, siswa mempunyai kelebihan dan kekurangan yang berbeda-beda. Ada siswa yang sudah lancar dalam membaca tapi tak pandai hafalan, ada juga siswa yang bisa dengan baik namun buruk dalam pelafalan makhrojul hurufnya karena tidak tau akan ilmu tajwid, dan lain-lain.

\section{Minat}

Kesulitan belajar siswa tidak hanya bersumber dari kemampuan siswa namun, kesulitan belajar yang dialami oleh siswa tak luput dari berbagai faktor. Faktor-faktor yang menjadi penyebab kesulitan belajar itu ada banyak sekali, entah itu dari faktor intern maupun dari faktor ekstern. Diantaraya yang menjadi faktor intern yaitu kurangnya minat belajar siswa seperti yang diungkapkan oleh Ustaz Banyu Pratama Udali:

"Dalam pembelajaran Al Qur'an Hadits ada sebagian siswa yang kurang menyukai pembelajaran Al Qur'an Hadits karena mereka banyak yang mengangap bahwa pembelajaran Al Qur'an Hadits adalah suatu pembelajaran yang sulit untuk dicerna dan dipahami".

Sesuai dengan temuan dan hasil observasi yang dilakukan peneliti mengenai hal yang menjadikan peserta didik berkesulitan dalam pembelelajaran AI-Qur'an Hadist maka peneliti akan membahas tentang bagaimana menyikapi kendala yang terjadi pada peserta didik secara spesifik pada pembahasan selajutnya.

4. Kesulitan Belajar Yang Di Hadapi Oleh Peserta Didik Pada Mata Pelajaran AI-Qur'an Hadist Di MTs Nurul ljtihad NW Tenang

Berdasarkan hasil wawancara yang diperoleh oleh peneliti di lapangan mengenai kesulitan belajar dalam mata pelajaran Al-Qur'an Hadits adalah siswa mengalami kesulitan membaca Al-Qur'an dan makharojul huruf karena pelajaran tersebut dinilai cukup sulit. Aktivitas belajar bagi setiap individu, tidak selamanya dapat berlangsung secara wajar. Kadang-kadang lancar, kadang-kadang tidak lancer, kadang-kadang dapat cepat menangkap apa yang dipelajarai, kadangkadang terasa amat sulit. Dalam hal semangat terkadang semangatnya tinggi, tetapi terkadang juga sulit untuk mengadakan konsentrasi (Abu Ahmadi dan Widodo Sopriyono, 2004:77).

Pelajaran Al-Qur'an Hadits adalah pelajaran yang kebanyakan berisi tentang ayatayat Al-Qur'an dan Hadits, sehingga banyak sekali hal-hal yang harus diperhatikan, mengingat Al-Qur'an dan Hadits adalah bahasa Arab. Sehingga dalam hal membacanya, harus sesuai dengan hukum bacaannya. Siswa harus rajin belajar membaca atau 
mengucapkan lambang-lambang bunyi (huruf) tertulis. Walaupun kegiatan ini tampak sederhana, namun untuk bisa membaca Al-Qur'an yang baik dan benar harus memperhatikan makhrojul hurufnya.

Selain kesulitan membaca Al-Qur'an, siswa juga mengalami kesulitan menghafal. Menghafal Al-Qur'an dan Hadits adalah sebagai langkah awal untuk memahami isi kandungan Al-Qur'an dan juga Hadits. Akan tetapi, hal itu tidak bisa terlepas dari berbagai macam kendala yang dihadapi oleh siswa, secara garis besar sebagai berikut:

a. Menghafal itu susah

b. Ayat-ayat yang sudah dihafal cenderung lupa lagi

c. Banyaknya ayat-ayat yang serupa

d. Gangguan kejiwaan

e. Gangguan lingkungan

f. Banyaknya kesibukan, dan lain-lain. Demikian yang dikemukakan oleh Ahsin W AlHafiz (1994:41).

Melihat kendala yang menjadikan siswa mengalami kesulitan belajar diatas, maka dibutuhkan kebiasaan membaca berulang-ulang agar materi yang dihafalkan mudah untuk diingat. Untuk itu diharuskan peserta didik untuk membiasakan diri membaca dengan benar dan membiasakan diri untuk menghafal. Sebagaimana ungkapan ulama' yang terkuak dalam syair:

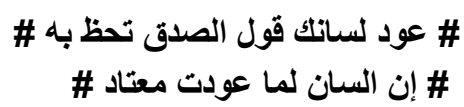

"\# biasakan lisanmu dengan perkataan dan ucapan yang benar, beruntung engkau dengannya \# Sesungguhnya lisan mana kala di di biasakan makan akan terbiasa \#". Demikian yang diungkapkan oleh Assyeikh Hafiz Hasan Al Mas'udiy (14).

Disisi lain guru juga berperan penting bagi peserta didik sebagai sang motivator yang senantiasa memberikan motivasi, dukungan spiritual serta dorongan kepada peserta didik untuk terus menanamkan dalam diri peserta didik agar menumbuhkan kebiasaan giat belajar, membaca dan menghafal khusunya pada mata pelajaran al-qur'an hadist.

5. Strategi yang Dilakukan Guru Al-Qur'an Hadits Dalam Mengatasi Kesulitan Belajar.

Pembelajaran adalah suatu proses yang mengandung serangkaian perbuatan guru dan siswa atas dasar hubungan timbal balik yang berlangsung dalam situasi edukatif dan efisien. Demikian yang di ungkapkan oleh B Suryobroto (2002:57).

Untuk itu, guru Al-Qur'an Hadits tidak hanya memberikan kiat-kiat belajar, tetapi mengaplikasikannya dalam proses pembelajaran. Adapun beberapa bentuk strategi guru Al-Qur'an Hadits dalam mengatasi kesulitan belajar pada mata pelajaran Al-Qur'an Hadits, di antaranya:

a. Pemberian Motivasi

Pemberian motivasi yang menyenangkan dapat menjadikan semangat siswa dalam belajar. motivasi sendiri berasal dari bahasa inggris motivation yang berarti dorongan. Kata kerjanya adalah to motivate yang berarti mendorong, menyebabkan, dan merangsang. Demikian yang dikatakan oleh Hamzah B. Uno (2013:3). Dengan demikian motivasi merupakan dorongan yang terdapat pada diri seseorang untuk berusaha mengadakan perubahan tingkah laku yang lebih baik dalam memenuhi kebutuhannya. Motivasi kepada kepada siswa sangatlah penting, karena dengan pemberian motivasi akan memberikan semangat pada siswa sehingga menimbulkan minat, perhatian dan kemauan siswa untuk belajar. Memberikan motivasi kepada siswa dengan cara menyadarkan atau mengingatkan tentang pentingnya belajar Al-Qur'an 
Hadis, dan memberikan semangat kepada siswa untuk selalu belajar sehingga menjadikan siswa haus akan pengetahuan dan prestasi.

b. Penggunaan Fasilitas Sarana dan Prasarana

Tersedianya sarana dan prasarana merupakan salah satu faktor penunjang dalam pencapaian keberhasilan proses belajar mengajar di sekolah. Karena dengan tersediannya sarana dan prasarana yang lengkap, dapat memudahkan para siswa dalam menerima pelajaran. Tentunya dalam hal ini yang di maksud adalah alat bantu pembelajaran, yaitu segala sesuatu yang dapat menunjang keefektifan dan efesiensi pembelajaran. Demikian yang dikatakan oleh Sudirman N (2000:208).

c. Google Classroom

Google classroom merupakan sebuah aplikasi yang diciptakan oleh Google yang memungkinkan terciptanya ruang kelas di dunia maya. Selain itu aplikasi ini menjadi sarana dikumpulkannya tugas-tugas. Demikian dikatakan oleh Noordin Asnawi (2018:17-21). Kreativitas guru dalam memanfaatkan kemajuan teknologi pada musim pandemic COVID-19 ini patut untuk diberi apresiasi yang tinggi. Dengan menggunakan google classroom pastinya akan memberikan pengalaman belajar yang baik antara guru dan siswa saat melakukan kegiatan belajar mengajar pada musim Pandemi COVID-19.

d. Kegiatan Madrasah Diniyah

Kegiatan madin adalah kegiatan yang memungkinkan siswa mengembangkan diri dengan kebiasaan belajar yang baik. Kegiatan Madin dillaksanakan setiap hari sebelum jam pelajaran formal berlangsung. Dalam kelas madin tersebut dibagi menjadi beberapa kelas, antara lain kelas iqra', kelas Al-Qur'an, dan kelas kitab. Pengadaan kelas ini bertujuan untuk memudahkan guru dalam pemberian materi secara maksimal.

\section{SIMPULAN}

Berdasarkan hasil penelitian dan pembahasan mengenai Strategi guru dalam mengatas kesulitan belajar pada mata pelajaran Al-Qur'an Hadis di MTs Nurul ljtihad NW Tenang, maka hasil penelitian dapat disimpukan bahwa: 1) Kesulitan belajar yang dihadapi oleh siswa pada mata pelajaran AIQur'an Hadits di MTs Nurul ljtihad NW Tenang yaitu, kesulitan membaca Al-Qur'an, dan Kesulitan menghafal ayat Al-Qur'an dan Hadits; dan 2) Strategi yang dilakukan guru dalam mengatasi kesulitan belajar siswa pada mata pelajaran Al-Qur'an Hadits di MTs Nurul ljtihad NW Tenang yaitu, Pemberian motivasi yang menyenangkan, Penggunaan media LCD proyektor, Penggunaan aplikasi google classroom dan Partisipasi guru dalam program madrasah diniyah.

\section{DAFTAR PUSTAKA}

Ahmad. (1985). Metodologi Pengajaran Pendidikan Agama Islam. Jakarta: Direktorat Jenderal Pembinaan Kelembagaan Agama Islam.

Ahmadi, A dan Widodo. S. (2004) Psikologi Belajar, Jakarta: Rineka Cipta.

Al-Hafidz, A. W. (1994). Bimbingan Praktis Menghafal Al-Qur'an. Jakarta: Bumi Aksara.

Ali, Z. (2007). Pendidikan Agama Islam. Jakarta: Bumi Aksara.

Al-Qur'an dan Terjemahan. (2010). Qs. Al Mujadalah: 11, Bandung, Cv. Jabal Raudtil Jannah

Aminuddin, et all. (2005) Pendidikan Agama Islam Untuk Perguruan Tinggi Umum (Bogor: Ghalia Indonesia,

Basuki dan Ulum, M. (2007). Pengantar Ilmu Pendidikan Islam. Yogyakarta: STAIN Po PREES, 
Dalyono, M. (2007). Psikologi Pendidikan. Jakarta: Rineka Cipta. Djamarah, S. B. (2013). Psikologi Belajar. Jakarta: Rianeka Cipta. Fadillah, M. (2018). Buku Ajar Bermain Dan Permainan. Jakarta: Prenamedia Group. Hakim, A. A, (2004). Metodologi Studi Islam, Bandung: PT. Remaja Roesdakarya Offset. Moleong. L. J. (2013). Metode Penelitian Kualitatif. Bandung: Remaja Rosdakarya. Mulyono, A. (2003). Pendidikan Bagi Anak Berkesulitan Belajar. Jakarta: Rineka Cipta. Noordin, A. (2018). "Pengukuran Usability Aplikasi Google Classroom Sebagai E-Learning Menggunakan USE Questionnaire (Studi Kasus: Prodi System Informasi UNIPMA"), Research: Journal of Computer, Information System, \& Technology Management, Vol. 1 , No.2.

Rahman, F. (1970). Ikhtisar Mustalahul Hadist. Bandung: PT. Al-Ma'rif.

Rahmatullah, A. M. (2018). Ilmu Pendidikan.

Ridho, P. S. (2019). Strategi Guru Dalam Menghadapi Kesulitan Belajar Siswa Pada Mata Pelajaran Al-Qur'an Hadist di MTsN 05 Tulungagung.

Safi'i, A. Metodologi Penelitian Pendidikan, Surabaya: Elkaf.

Sanjaya, W. (2009). Strategi Pembelajaran Berorientasi Standar Proses Pendidikan. Jakarta: Kencana Prenaa Media Group.

Sardiman, A. M. (2011). Interaksi dan Motivasi Belajar Mengajar. Jakarta: Rajawali Pers. Persada.

Sardiman. (2011). Motivasi Learning. Jakarta: Rineka Cipta.

Slameto. (2008). Belajar dan Faktor-Faktor Mempengaruhinya. Jakarta: Rineka Cipta.

Sudirman, N. (2000). Ilmu Pendidikan. Bandung: Remaja Rosdakarya.

Sugiyono. (2013). Metode Penelitian Pendidikan Kuantitatif, Kualitatif dan R\&D. Bandung: Alfabeta.

Sujana, N. (2008). Pembinaan dan Pengembangan Kurikulum Sekolah. Bandung: Sinar Baru AL Gasindo.

Suryobroto, B. (2002), Proses Belajar Mengajar di Sekolah, Jakarta: Rineka Cipta.

Syah, M. (2006). Psikologi Belajar. Jakarta: Raja Grafindo Persada.

Syeikh Hafiz Hasan al-mas'udiy, Durussul Akhlak (Surabaya: Al - Hidayah).

Uno, H. B. (2013). Teori Motivasi dan Pengukurannya. Jakarta: Bumi Aksara. 